\title{
Heritability of rectal temperature and genetic correlations with production and reproduction traits in dairy cattle
}

\author{
S. Dikmen, ${ }^{*}$ J. B. Cole, $†$ D. J. Null, $†$ and P. J. Hansen $\ddagger^{1}$ \\ *Department of Animal Science, Faculty of Veterinary Medicine, Uludag University, Bursa, 16059, Turkey \\ †Animal Improvement Programs Laboratory, Agricultural Research Service, USDA, Beltsville, MD 20705-2350 \\ ‡Department of Animal Sciences, University of Florida, Gainesville 32611-0910
}

\section{ABSTRACT}

Genetic selection for body temperature during heat stress might be a useful approach to reduce the magnitude of heat stress effects on production and reproduction. Objectives of the study were to estimate the genetic parameters of rectal temperature (RT) in dairy cows in freestall barns under heat stress conditions and to determine the genetic and phenotypic correlations of rectal temperature with other traits. Afternoon RT were measured in a total of 1,695 lactating Holstein cows sired by 509 bulls during the summer in North Florida. Genetic parameters were estimated with Gibbs sampling, and best linear unbiased predictions of breeding values were predicted using an animal model. The heritability of RT was estimated to be $0.17 \pm 0.13$. Predicted transmitting abilities for rectal temperature changed $0.0068 \pm 0.0020^{\circ} \mathrm{C} / \mathrm{yr}$ from (birth year) 2002 to 2008. Approximate genetic correlations between RT and 305-d milk, fat, and protein yields, productive life, and net merit were significant and positive, whereas approximate genetic correlations between RT and somatic cell count score and daughter pregnancy rate were significant and negative. Rectal temperature during heat stress has moderate heritability, but genetic correlations with economically important traits mean that selection for RT could lead to lower productivity unless methods are used to identify genes affecting RT that do not adversely affect other traits of economic importance.

Key words: heritability, rectal temperature, heat stress

\section{INTRODUCTION}

Heat stress has adverse effects on milk production and reproduction of dairy cattle (Kadzere et al., 2002; West, 2003; Hansen, 2007). As noted by Hansen (2007), the problem of heat stress is growing because of in-

Received February 24, 2011.

Accepted February 7, 2012.

${ }^{1}$ Corresponding author: pjhansen@ufl.edu creases in milk yield that result in higher metabolic heat production and because of anticipated changes in the global climate. Genetic selection for core body temperature regulation is one potential strategy to mitigate effects of heat stress on dairy cows. Most of the negative effects of heat stress on animal performance are either a consequence of the physiological adaptations that homeotherms undergo to regulate body temperature or the adverse consequences of failure to regulate body temperature (Hansen, 2011). Thus, an animal with genetic adaptations that make for more effective regulation of core body temperature will experience a less severe reduction in production. This idea has been documented in dairy cattle by comparing milk production in a hot climate for cows that are genetically superior for body temperature regulation by virtue of inheritance of the slick hair gene (Olson et al., 2003) or a specific allele of ATP1A1 (Liu et al., 2011). In both cases, cattle with the genotype that favors body temperature regulation had greater milk yield than cattle with the less favorable genotype.

Core body temperature is commonly ascertained by measuring rectal temperature. If rectal temperature (RT) during heat stress is heritable, it might be possible to improve thermotolerance of dairy cattle by selection for this trait. Heritability of RT in dairy cattle was reported to range from 0.15 to 0.31 (Seath, 1947), but changes in production level and environment since that study was conducted may have caused a change in heritability.

The current study had 2 objectives. The first was to estimate the genetic parameters of RT in dairy cattle subjected to heat stress. The second was to estimate genetic and phenotypic correlations of RT with production and reproduction traits.

\section{MATERIALS AND METHODS}

\section{Rectal Temperature}

The study was conducted with lactating Holstein cows at 3 dairies: the University of Florida Dairy Unit 
(Hague, FL; $29^{\circ} 46^{\prime} \mathrm{N}$ and $82^{\circ} 24^{\prime} \mathrm{W} ; \mathrm{n}=581$ ), Alliance Dairy (Trenton, FL; $29^{\circ} 35^{\prime} \mathrm{N}$ and $82^{\circ} 51^{\prime} \mathrm{W} ; \mathrm{n}=810$ ), and Hilltop Dairy (Trenton, FL; $29^{\circ} 35^{\prime} \mathrm{N}$ and $82^{\circ} 52^{\prime} \mathrm{W}$; $\mathrm{n}=304)$. Herd size was approximately 450 lactating cows (University of Florida), 6,000 lactating cows (Alliance), and 3,000 lactating cows (Hilltop). At each farm, cows were housed in freestall barns equipped with fans and sprinklers, and cows were fed total mixed rations. Rectal temperature was measured in 2,353 randomly selected lactating Holstein cows. Of these, records were used from 1,695 cows for which pedigree and production data were available. The 1,695 cows were sired by 509 progeny-tested AI bulls. Each cow was measured once during the experiment. Rectal temperature data were collected during the years $2007(\mathrm{n}=745)$ and $2010(\mathrm{n}=950)$ from June to September. Details of RT and environmental data for cows collected in 2007 were reported by Dikmen and Hansen (2009).

Rectal temperatures were recorded between 1500 and $1700 \mathrm{~h}$ using a digital GLA M750 thermometer (GLA Agricultural Electronics, San Luis Obispo, CA). Cows were measured while in head-locks in the freestall barn and while under shade. Measurements of dry bulb temperature $\left(\mathbf{T}_{\mathrm{db}}\right)$, relative humidity $(\mathbf{R H})$, dew point temperature $\left(\mathbf{T}_{\mathrm{dp}}\right)$, and black globe temperature $\left(\mathbf{T}_{\mathrm{bg}}\right)$ were measured at 1-min intervals between 1500 and $1700 \mathrm{~h}$ using a Hobo-U12 data logger $\left(\mathrm{T}_{\mathrm{db}}, \mathrm{RH}\right.$, and $\mathrm{T}_{\mathrm{dp}}$ ) and a Hobo Water Temp Pro V2 data logger $\left(\mathrm{T}_{\mathrm{bg}}\right)$ (Onset Computer Corp., Bourne, MA) that were located at a height of $2 \mathrm{~m}$ from the ground at a position in the center of the barn where cows were housed. Rectal temperature was matched with the measurements of $\mathrm{T}_{\mathrm{db}}, \mathrm{RH}, \mathrm{T}_{\mathrm{dp}}$, and $\mathrm{T}_{\mathrm{bg}}$ to the nearest minute at which environmental variables were recorded.

Temperature-humidity index (THI) was calculated as follows (National Research Council, 1971):

$$
\begin{aligned}
\mathrm{THI}=(1.8 \times & \left.\mathrm{T}_{\mathrm{db}}+32\right)-[(0.55-0.0055 \times \mathrm{RH}) \\
& \left.\times\left(1.8 \times \mathrm{T}_{\mathrm{db}}-26.8\right)\right] .
\end{aligned}
$$

\section{Performance and Pedigree Data}

Rectal temperatures were matched with performance data from the test-day closest to the date on which RT measurements were taken and included production and reproduction data for first through fifth lactations collected through the national milk recording program. Data were taken from the national dairy database (NDDB) maintained by the Animal Improvement Programs Laboratory (Beltsville, MD) and included PTA of milk, fat, and protein yields; SCS; productive life (PL; VanRaden and Wiggans, 1995); daughter pregnancy rate (DPR; VanRaden et al., 2004); and lifetime
Table 1. Average $( \pm \mathrm{SE})$ and range of animal and environmental variables used in the analysis

\begin{tabular}{lcc}
\hline Item $^{1}$ & Mean $( \pm \mathrm{SE})$ & Range \\
\hline Rectal temperature $\left({ }^{\circ} \mathrm{C}\right)$ & $39.0 \pm 0.6$ & 37.2 to 41.7 \\
Daily milk yield $(\mathrm{kg})$ & $32.5 \pm 12.5$ & 3.0 to 80.0 \\
Parity & $2.1 \pm 0.9$ & 1 to 4 \\
$\mathrm{DIM}$ & $172.2 \pm 126.4$ & 3 to 896 \\
$\mathrm{~T}_{\mathrm{db}}\left({ }^{\circ} \mathrm{C}\right)$ & $30.6 \pm 3.4$ & 18.5 to 38.9 \\
$\mathrm{RH}(\%)$ & $63.2 \pm 11.5$ & 32.5 to 92.4 \\
$\mathrm{~T}_{\mathrm{dp}}\left({ }^{\circ} \mathrm{C}\right)$ & $22.5 \pm 2.9$ & 9.1 to 28.1 \\
$\mathrm{~T}_{\mathrm{bg}}\left({ }^{\circ} \mathrm{C}\right)$ & $30.8 \pm 3.6$ & 18.5 to 38.6 \\
$\mathrm{THI}$ & $81.0 \pm 4.3$ & 65.1 to 88.2 \\
\hline
\end{tabular}

${ }^{1} \mathrm{~T}_{\mathrm{db}}=$ dry bulb temperature; $\mathrm{RH}=$ relative humidity; $\mathrm{T}_{\mathrm{dp}}=$ dewpoint temperature; $\mathrm{T}_{\mathrm{bg}}=$ black globe temperature; $\mathrm{THI}=$ temperature-humidity index.

net merit (NM\$; Cole et al., 2010). A pedigree file, including male and female ancestors back to 1960, was obtained from the NDDB and included 3,381 individuals. Summary statistics for daily milk yield on the days when RT was measured, parity, DIM, and environmental variables are shown in Table 1 .

\section{Genetic (Co)variances and PTA for RT}

Mixed model analysis was performed using PROC MIXED of SAS (version 9.1.3; SAS Institute Inc., Cary, $\mathrm{NC}$ ) with RT as the dependent variable to identify factors that should be included in the genetic model. Explanatory variables in the initial model included year of data collection, farm, parity, stage of lactation [separated into 3 stage of lactation classes: DIM $<100$ ( $\mathrm{n}=$ 741); DIM between 100 and $200(\mathrm{n}=389)$; and DIM $>200(\mathrm{n}=565)]$, and THI. The final model included effects of parity $(P<0.0001)$, stage of lactation $(P<$ $0.0001)$, and farm $(P<0.0001)$ as class variables, and THI $(P<0.0001)$ and test-day milk yield $(P<0.10)$ as covariates.

The model used for estimation of genetic and environmental effects was

$$
\mathbf{y}=\mathbf{X b}+\mathbf{Z a}+\mathbf{e},
$$

where $\mathbf{y}$ is a vector of $\mathrm{RT}, \mathbf{b}$ is a vector of fixed effects, $\mathbf{a}$ is a vector of additive genetic effects, and $\mathbf{e}$ is a vector of random residual effects. Fixed effects included parity, year of data collection, stage of lactation, and farm; THI and milk yield at the time of measurement were included as covariates. $\mathbf{X}$ and $\mathbf{Z}$ are incidence matrices relating a record to fixed environmental effects in $\mathbf{b}$ and to a random animal effect in a, respectively.

(Co)variances for RT were estimated using the Gibbs sampling method with the GIBBS1F90 software package (Misztal et al., 2002). Prior distributions were flat for the fixed effects and normal for the animal effect. 
One Gibbs chain of 100,000 samples was drawn, the first 10,000 samples were discarded as burn-in, and then every tenth sample from the remaining 90,000 samples was used to calculate posterior means of the (co)variance components. Posterior means and standard deviations of the (co)variances were computed using POSTGIBBSF90 (Misztal et al., 2002). Plots of the Gibbs samples for each of the random effects were examined and no trends were observed, and it was concluded that a longer burn-in period was not needed. The heritability of RT was calculated from the resulting (co)variances, and its standard error was calculated using the Delta method (Lynch and Walsh, 1998).

Predicted transmitting abilities and reliabilities for RT were obtained using the MTDFREML software package (Boldman et al., 1993), which provides BLUP of breeding values upon convergence. (Co)variance components were those calculated in the previous step. Convergence was defined as a change in -2(log-likelihood) between successive rounds of iteration of 10-6 or less, and was achieved after 108 rounds of iteration. Summary statistics for daily milk yield on the days when RT was measured, parity, DIM, and environmental variables are shown in Table 1.

\section{Phenotypic and Genetic Correlations}

Data on individual cows were used to calculate Pearson correlations for phenotypic values of RT, yield, SCS, DPR, and PL (RT measured on the farm and other values obtained from NDDB).

Data on RT were available for only 1,695 phenotypes, so genetic correlations of RT with the other traits were approximated using the method of Calo et al. (1973), rather than by a series of pairwise models. Genetic correlations were calculated from the PTA for 148 bulls included in the pedigree file that had a reliability for $\mathrm{NM} \$$ of at least 0.85 (taken from the NDDB) and a reliability for RT at least 0.25 (average reliability of RT $=0.289 \pm 0.04)$. Genetic correlations were estimated as a function of correlations among PTA and their reliabilities ( $\mathrm{n}=148$ bulls) using the method of Calo et al. (1973):

$$
\hat{r}_{\mathrm{g} 1,2}=\frac{\sqrt{\left(\Sigma R L_{1}\right) \times\left(\Sigma R L_{2}\right)}}{\Sigma\left(R L_{1} \times R L_{2}\right)} \times r_{1,2},
$$

where $\hat{r}_{\mathrm{g} 1,2}=$ approximate genetic correlation between traits 1 and $2 ; \Sigma R L_{1}$ and $\Sigma R L_{2}=$ the sum of reliabilities of traits 1 and $2 ; R L_{1}$ and $R L_{2}=$ reliabilities of traits 1 and 2 ; and $r_{1,2}=$ correlation between PTA for traits 1 and 2 . Standard errors $( \pm \mathrm{SE})$ of the approximate genetic correlations were estimated as:

$$
\mathrm{SE}=\sqrt{\frac{1-\hat{r}_{\mathrm{g} 1,2}}{n-2}}
$$

where $n=$ number of bulls with records (Sokal and Rohlf, 1995). Genetic trends were estimated by regression of PTA of cows on birth year.

\section{RESULTS AND DISCUSSION}

\section{RT Heritability Estimates}

Genetic and total variance of RT was $0.06 \pm 0.03$ and $0.28 \pm 0.07$, respectively (estimate \pm standard error). The heritability of RT was estimated to be 0.17 \pm 0.13 , which is similar to the low end of the range of estimates of Seath (1947; 0.15 to 0.31). The latter study involved analysis of records from the 8 warmest days on which RT were recorded on 99 lactating Holsteins and Jerseys over $2 \mathrm{yr}$ in the summer and autumn (year $1 ; \mathrm{h}^{2}=0.15$ ) or summer (year $2 ; \mathrm{h}^{2}=0.31$ ). Thus, the large increase in milk yield of dairy cows and changes in housing conditions since the 1940s does not appear to have altered the heritability of RT substantially. The heritability estimate of RT is greater than or similar to that of several traits currently evaluated, such as DPR (0.04), PL (0.08), and SCS (0.12), which account for $43 \%$ of the relative emphasis in lifetime net merit (Cole et al., 2010). The determination of how much weight RT should receive in selection objectives will depend on the economic value of RT and its genetic correlation with other traits, rather than the magnitude of its heritability. Moreover, the large standard error of the estimate of heritability means that accuracy of the estimate could be improved by analysis of more records.

\section{Genetic Trend for RT}

Genetic trend for RT was estimated by regression of PTA for RT on birth year. Because so few data on RT were available for cows before the birth year of 2002 (4 to 11 observations/yr), results do not include observations before January 1, 2002. Predicted transmitting abilities for RT increased between 2002 and 2008 at an average rate of $0.0068 \pm 0.0020^{\circ} \mathrm{C} / \mathrm{yr}$.

\section{Genetic and Phenotypic Correlations}

Approximate genetic correlations between RT and 305-d milk, fat, and protein yields, PL, and $\mathrm{NM} \$$ were significant and positive, whereas those between RT and SCS and DPR were significant and negative (Table 2). Thus, selection of reduced RT could have adverse effects on genetic merit for production traits, $\mathrm{NM} \$, \mathrm{PL}$ 
Table 2. Approximate genetic correlations $( \pm \mathrm{SE})$ of rectal temperature with other traits

\begin{tabular}{lcc}
\hline Trait & $\begin{array}{c}\text { Genetic } \\
\text { correlation }\end{array}$ & SE \\
\hline 305-d Milk yield & $0.090^{*}$ & 0.006 \\
305-d Fat yield & $0.096^{*}$ & 0.006 \\
305-d Protein yield & $0.102^{*}$ & 0.006 \\
305-d SCS & $-0.010^{*}$ & 0.007 \\
Productive life & $0.061^{*}$ & 0.006 \\
Daughter pregnancy rate & $-0.013^{*}$ & 0.007 \\
Net merit & $0.122^{*}$ & 0.006 \\
\hline$P<0.05$ & &
\end{tabular}

$* P<0.05$.

and SCS while having beneficial effects on DPR. That genetic merit for RT is adversely related to genetic merit for yield traits is not surprising given that cows that produce more milk generate more heat (Holter, 1976). Similarly, the magnitude of the decrease in fertility caused by heat stress is related to the magnitude of hyperthermia (Gwazdauskas et al., 1973) so it is logical that cows with genetic merit for higher RT would have lower genetic merit for DPR. The only surprising result was the negative genetic correlation between RT and SCS as it implies that genetic merit for high RT reduced inflammation in the mammary gland and, by inference, mastitis. This correlation, which was small, is unexpected because the incidence of mastitis can be greater during summer (Hogan et al., 1989; Elvinger et al., 1991; Makovec and Ruegg, 2003), and heat stress has been reported to decrease the migratory response of PMNL in the mammary gland (Elvinger et al., 1992).

Phenotypic correlations among RT and other traits are shown in Table 3. We observed significant and positive correlations of RT with fat and protein yields, and significant and negative correlations of RT with SCS and PL. Correlations of RT with milk yield and DPR were not statistically different from zero.

To the extent that RT is a proxy for an animal's ability to resist heat stress, it should be possible to select cows that are more thermotolerant. This conclusion is consistent with that of Oseni et al. (2004), who reported genetic variation in thermal resistance with respect to days open. Genetic selection for RT should be performed using methods that prevent selection for undesirable genes affecting production traits, $\mathrm{NM} \$$, and SCS, such as a restricted selection index (Cunningham et al., 1970). A more sophisticated approach would combine information about genetic markers associated with RT but not other traits with PTA from all traits into a selection criterion (Lande and Thompson, 1990). Given the array of molecules involved in regulation of body temperature and cellular responses to hyperthermia, it is likely that many genes contain allelic variants that affect thermotolerance. One such SNP that determines heat stress resistance has been identified in ATP1A1 in Holsteins (Liu et al., 2011) and likely, other such genes will be identified.

The heritability estimate for RT had a large error and approached zero at the lowest part of the range. Work is currently underway to collect additional phenotypes from a broader range of herds, which will permit the more precise estimation of genetic correlations. The economic value of RT is also being studied to determine how it might best be incorporated into selection objectives. Nonetheless, data indicate that genetic variation for RT exists in Holsteins and it may be feasible to select for decreased RT during summer months to improve resistance to heat stress. Doing so should be carried out using methods that do not result in inadvertent selection against traits contributing to the economic performance of dairy cows.

\section{ACKNOWLEDGMENTS}

This study was supported by National Research Initiative Competitive Grant number 2010-85122-20623 from the USDA National Institute of Food and Agriculture and by grant number BAP YDP(V) 2010/15 from the Scientific Research Project Directorship of Uludag University. The authors thank the following for providing access to cows and records: Eric Diepersloot of the University of Florida Dairy Research Unit (Hague, FL); Ron St. John and the employees of Alliance Dairy (Trenton, FL); and Pam Bliss and the employees of Hilltop Dairy (Trenton, FL). The cooperation of the Holstein Association USA (Brattleboro, VT) in supplying pedigree data for registered cows and the dairy records processing centers AgriTech Analytics (Visalia, CA), AgSource Cooperative Services (Verona, WI), Dairy Records Management Systems (Raleigh, NC, and Ames, IA), and DHI Computing Services (Provo, UT) in supplying pedigree data for grade cows and lactation yield data is acknowledged. Two anonymous reviewers and the editor are thanked for providing comments and suggestions that greatly improved the manuscript.

Table 3. Phenotypic correlations with rectal temperature and production traits

\begin{tabular}{lc}
\hline Trait & Correlation \\
\hline 305-d Milk yield & -0.016 \\
305-d Fat yield & $0.067^{* *}$ \\
305-d Protein yield & $0.090^{* * *}$ \\
305-d SCS & $-0.077^{* * *}$ \\
Productive life & $-0.089^{*}$ \\
Daughter pregnancy rate & 0.032 \\
\hline
\end{tabular}

${ }^{*} P<0.05 ;{ }^{* *} P<0.01 ;{ }^{* * *} P<0.001$. 


\section{REFERENCES}

Boldman, K. G., L. A. Kriese, L. D. Van Vleck, C. P. Van Tassell, and S. D. Kachman. 1993. MTDFREML. A set of programs to obtain estimates of variances and covariances. USDA, Agric. Res. Ser., Washington, DC.

Calo, L. L., R. E. McDowell, L. D. VanVleck, and P. D. Miller. 1973. Genetic aspects of beef production among Holstein-Friesians pedigree selected for milk production. J. Anim. Sci. 37:676-682.

Cole, J. B., P. M. VanRaden, and Multi-State Project S-1040. 2010. AIPL Research Report NM $\$ 4$ : Net merit as a measure of lifetime profit: 2010 revision. Accessed Feb. 10, 2011. http://aipl.arsusda. gov/reference/nmcalc.htm.

Cunningham, E. P., R. A. Moen, and T. Gjedrem. 1970. Restriction of selection indices. Biometrics 26:67-74.

Dikmen, S., and P. J. Hansen. 2009. Is the temperature-humidity index the best indicator of heat stress in lactating dairy cows in a subtropical environment? J. Dairy Sci. 92:109-116.

Elvinger, F., R. C. Littell, R. P. Natzke, and P. J. Hansen. 1991. Analysis of somatic cell count data by a peak evaluation algorithm to determine inflammation events. J. Dairy Sci. 74:3396-3406.

Elvinger, F., R. P. Natzke, and P. J. Hansen. 1992. Interactions of heat stress and bovine somatotropin affecting physiology and immunology of lactating cows. J. Dairy Sci. 75:449-462.

Gwazdauskas, F. C., W. W. Thatcher, and C. J. Wilcox. 1973. Physiological, environmental, and hormonal factors at insemination which may affect conception. J. Dairy Sci. 56:873-877.

Hansen, P. J. 2007. Exploitation of genetic and physiological determinants of embryonic resistance to elevated temperature to improve embryonic survival in dairy cattle during heat stress. Theriogenology 68:S242-S249.

Hansen, P. J. 2011. Heat stress and climate change. Pages 477-485 in Comprehensive Biotechnology. 2nd ed. Vol. 4. M. Moo-Young, ed. Elsevier, Amsterdam, the Netherlands.

Hogan, J. S., K. L. Smith, K. H. Hoblet, P. S. Schoenberger, D. A. Todhunter, W. D. Hueston, D. E. Pritchard, G. L. Bowman, L. E. Heider, and B. L. Brockett. 1989. Field survey of clinical mastitis in low somatic cell count herds. J. Dairy Sci. 72:1547-1556.

Holter, J. B. 1976. Fasting heat production in "lactating" versus dry dairy cows. J. Dairy Sci. 59:755-759.
Kadzere, C. T., M. R. Murphy, N. Silanikove, and E. Maltz. 2002. Heat stress in lactating dairy cows: A review. Livest. Prod. Sci. 77:59-91.

Lande, R., and R. Thompson. 1990. Efficiency of marker-assisted selection in the improvement of quantitative traits. Genetics 124:743-756.

Liu, Y., L. Dagi, H. Li, and X. Zhou. 2011. A novel SNP of the AT$P 1 A 1$ gene is associated with heat tolerance in dairy cows. Mol. Biol. Rep. 38:83-88.

Lynch, M., and B. Walsh. 1998. Genetics and Analysis of Quantitative Traits. Sinauer Associates, Sunderland, MA.

Makovec, J. A., and P. L. Ruegg. 2003. Results of milk samples submitted for microbiological examination in Wisconsin from 1994 to 2001. J. Dairy Sci. 86:3466-3472.

Misztal, I., S. Tsuruta, T. Strabel, B. Auvray, T. Druet, and D. H. Lee. 2002. BLUPF90 and related programs (BGF90). Commun. No. 28-07 in Proc. 7th World Congr. Genet. Appl. Livest. Prod., Montpellier, France.

National Research Council. 1971. A Guide to Environmental Research on Animals. Natl. Acad. Sci., Washington, DC

Olson, T. A., C. Lucena, C. C. Chase Jr., and A. C. Hammond. 2003. Evidence of a major gene influencing hair length and heat tolerance in Bos taurus cattle. J. Anim. Sci. 81:80-90.

Oseni, S., S. Tsuruta, I. Misztal, and R. Rekaya. 2004. Genetic parameters for days open and pregnancy rates in US Holsteins using different editing criteria. J. Dairy Sci. 87:4327-4333.

Seath. D. M. 1947. Heritability of heat tolerance in dairy cattle. J. Dairy Sci. 30:137-144

Sokal, R. R., and F. J. Rohlf. 1995. Biometry: The Principles and Practice of Statistics in Biological Research. 3rd ed. W. H. Freeman and Company, New York, NY.

VanRaden, P. M., A. H. Sanders, M. E. Tooker, R. H. Miller, H. D. Norman, M. T. Kuhn, and G. R. Wiggans. 2004. Development of a national genetic evaluation for cow fertility. J. Dairy Sci. 87:2285-2292.

VanRaden, P. M., and G. R. Wiggans. 1995. Productive life evaluations: Calculation, accuracy, and economic value. J. Dairy Sci. $78: 631-638$

West, J. W. 2003. Effects of heat-stress on production in dairy cattle. J. Dairy Sci. 86:2131-2144. 